\title{
Formation of oat fresh yield and its protein yield in the conditions of the southern forest-steppe of Western Siberia
}

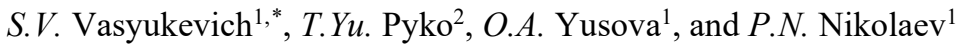 \\ ${ }^{1}$ Omsk Agrarian Research Center, Omsk, Russia \\ ${ }^{2}$ Omsk Agrarian Research Center, Tara, Russia
}

\begin{abstract}
The results of the study of grain and fodder oat varieties in the competitive variety trial of the Omsk Agrarian Research Center are discussed. The article provides data on the green food yield and its protein yield for the period from 2018 to 2020. The samples were tested under conditions with contrasting moisture content. Physiological indices of varieties are also analyzed: leaf area, accumulation and distribution of dry biomass as well as percentage of protein. The response of oat varieties by year to different weather conditions is shown. A favorable year has been identified for the formation of a common assimilating area of oat plants. It was revealed that the protein content in the vegetative mass of oats varies oppositely with the total yield. The accumulation of dry biomass in ontogenesis characterizes the photosynthetic activity of plants. It is in a positive relationship with their yieldability. The selection of grain and fodder oat varieties begins with the SP-2 nursery.
\end{abstract}

\section{Introduction}

From more than 14 billion only $10 \%$ of the world's agricultural land has favorable conditions for plant cultivation. Other factors limit the production of high yields on the remaining lands [1]. The use of new highly productive, stable varieties to environmental factors guarantees the yield of crop output with the safety of production resources and the environment [2].

Oat is a crop of great significance for animal husbandry. Together with feeder grain, the use of straw and green mass for food is done. For this purpose, the crop is grown in its pure form, as well as in a mixture with annual legumes for haying, silage, haylage and green food.

The Omsk Agrarian Research Center (until 2017 - Siberian Research Institute of Agriculture) has been involved in the selection of oats since the 1960s in three main areas of use: feeder grain, food grain, and fodder grain. There are certain achievements in all three areas in the research center. A number of varieties with high yield, adapted to the conditions of Western Siberia, resistant to biotic and abiotic environmental factors were created and zoned. Among them there are three naked varieties - Sibirsky naked, Progress, and

*Corresponding author: www.vsv55@mail.ru 
Tarsky naked. The productivity capacity of naked varieties is lower than that of chaffy varieties. It is caused, among other things, by the lack of selection work on their creation [3].

The sampling of selection samples is performed according to a number of features common to all areas: high grain yield, low percentage of coatings, double and empty grains, stability to grain shedding and straw lodging, resistance to diseases (crown rust and smut pathogens). For the feed mowing trend, the requirements are defined: a high yield of green mass and a high protein content in it.

The selection process is based on the intraspecific hybridization technique. For this reason, at the current level of complexity of selection problems, the demands for genetic data concerning the varieties (lines) used for hybridization for green feed are increasing, i.e., the evaluation of features by phenotype should be attended by their genetic characteristics. To ensure the success of the selection program, it is essential to use a well-studied source material containing signs marking yield and protein content as significant components of feed productivity. The selection programs of the laboratory contain samples which have been identified according to individual economic and valuable features and their complex.

An oat biological yield is governed by the following indicators of the production process of agrophytocenosis: the assimilating area, photosynthetic potential and the net productivity of photosynthesis [4]. Therefore, the aim of these analyses is to study the peculiarities of the formation of the main morphophysiological indicators of oat plants as factors of the formation of the green mass yield for the conditions of the southern forest-steppe of Western Siberia.

\section{Material and Methods}

The yield of the green mass of oat varieties in the competitive variety trial was conducted annually in 2018-2020. From 10 to 13 varieties were studied annually in the experiment. The mowing of the discount areas was performed in two periods: one and two weeks after ear formation, i.e., in the phase of the beginning of milky stage. A discount area $-2 \mathrm{~m}^{2}$ with the subsequent recalculation of the yield per 1 ha. 10 plants were selected in each sample for analysis according to the main photosynthetic indicators in the laboratory of genetics, biochemistry and physiology of plants. The following parameters were identified: leaf area [5], dry matter accumulation [6], protein content and collection from 1 ha for each variety [7]. The total assimilation area (TAA) is the total index of the leaf surface of the plant. The mathematical data processing, including variance and correlation analysis of features, was performed according to the handbook of B. A. Dospekhov [8] using Microsoft Excel.

\section{Results and Discussion}

The weather and climatic conditions of the territory of the Omsk region have a significant contrast, with sharp fluctuations in the values of meteorological factors (Figure 1).

The hydrothermal index calculated according to the formula of G. T. Selyaninov for Omsk is 1.13 [9].

Figure 1. The agrometeorological conditions from May to July according to "Omskaya" hydrometeostation data [10], (2018-2020). 

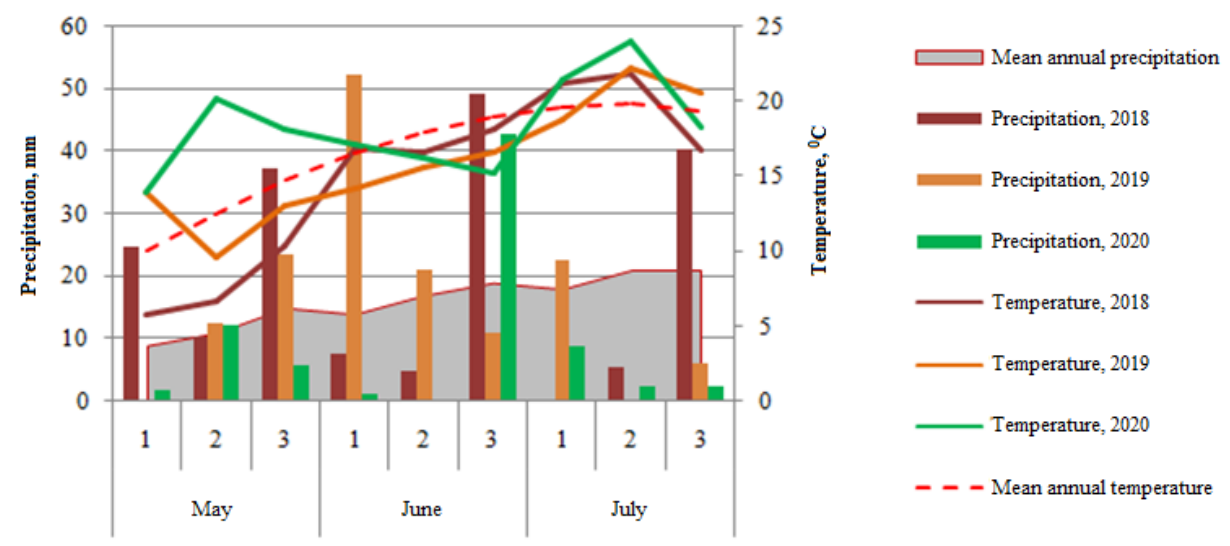

Fig. 1. The agrometeorological conditions from May to July according to "Omskaya" hydrometeostation data [10], (2018-2020).

In 2018, cool, rainy weather prevailed in the southern forest - steppe of the Omsk region in May-June, below the temperature norm. The amount of precipitation in May was 73 $\mathrm{mm}$, which is $37 \mathrm{~mm}$ more than the mean annual one, and in June $61.6 \mathrm{~mm}-123.2 \%$. In July, the average monthly air temperature was at the level of the mean annual temperature and amounted to $19.8 \mathrm{oC}\left(0.2^{\circ} \mathrm{C}\right.$ to the norm $)$. Precipitation fell less than normal $-45.5 \mathrm{~mm}$ ( $75.8 \%$ of the long-term mean values).

May 2019 was at the level of the mean annual norm. In June, cool rainy weather prevailed. A total of $84.5 \mathrm{~mm}$ of precipitation fell, which is $34.5 \mathrm{~mm}$ higher than normal index $(169 \%)$. The mean monthly air temperature was $15.5^{\circ} \mathrm{C}$. It is $2.37^{\circ} \mathrm{C}$ lower than the normal index $(86.8 \%)$. In July, the mean monthly air temperature was at the level of the mean annual temperature and was $20.5^{\circ} \mathrm{C}\left(0.8{ }^{\circ} \mathrm{C}\right.$ to the normal index, $\left.104.4 \%\right)$. Precipitation fell by $31.4 \mathrm{~mm}$ less than normal ( $47.7 \%$ of the long-term mean values).

The data analysis on the hydrothermal regime of the growing season characterizes the weather of 2019 as close to standard in temperature with overwetting at the beginning and drought at the end of the crop season. Thus, according to the data of Omskaya hydrometeostation, the weather conditions of the crop season of 2019 differed in contrast both in precipitation and temperature conditions. The humidity ranged from 49 to $75 \%$. There were favorable conditions for the growth and development of plants, as well as infection and manifestation of smut and rust diseases with epiphytotic manifestation in individual fields and varieties.

Therefore, 2018 and 2019 have become favorable for the development of leaf-stem diseases. The affect of crown rust reached $100 \%$, which contributed to an objective evaluation of the stability of the analyzed material.

May 2020 was described as hot and dry. A considerable shortage of precipitation was observed in the first and second decades of June, and the third decade was rainy. During the month, $44.2 \mathrm{~mm}$ of precipitation fell, which is 6.8 less than the norm $(86.7 \%)$. The mean monthly air temperature in July was $1,6^{\circ} \mathrm{C}$ higher than the long-term mean and was $21.2^{\circ} \mathrm{C}$ ( $108.2 \%$ to the normal index). The percentage of precipitation was $20.6 \%$ of the long-term mean values. The weather conditions of 2020 did not promote the development of leaf-stem diseases.

The weather conditions in the years of research directly impacted the height of plants (Table 1). In 2018, there was a lack of positive temperatures with high moisture availability in May. That is why the soil was not adequately warmed up at the time of sowing oats, so the "sowing-sprouting" period raised by five days. The sowing in cold, moist soil, com- 
bined with a lack of precipitation in June, also had a negative impact on the height of plants. It was smaller by $20-30 \mathrm{~cm}$ in comparison with that in the well-moisture 2019 . The negative effect of an oversupply of positive temperatures and a lack of moisture is clearly noticeable in the dry 2020. Meanwhile, it was observed that the precipitation which fell at the end of June, twice exceeding the norm, subsequently affected to the grain filling. The weight of 1000 grains was higher than the average for varieties.

Table 1. Height of KSI oat varieties per green mass $(2018-2020)$.

\begin{tabular}{|c|l|c|c|c|c|}
\hline \multirow{2}{*}{$\begin{array}{c}\text { Seq } \\
\text { No. }\end{array}$} & \multicolumn{1}{|c|}{ Variety } & \multicolumn{3}{|c|}{ Average height of plants, cm } & \multirow{2}{*}{$\overline{\mathrm{X}}$} \\
\cline { 2 - 5 } & & 2018 & 2019 & 2020 & 122 \\
\hline 1 & Irtysh 22, st. & 122 & 140 & 104 & 139 \\
\hline 2 & $\begin{array}{l}\text { Ural (Ural Research } \\
\text { Institute of Agriculture) }\end{array}$ & 132 & 157 & 128 & 121 \\
\hline 3 & Irtysh 33 & 115 & 145 & 104 & 116 \\
\hline 4 & Mutika 1201 & 120 & 137 & 92 & 119 \\
\hline 5 & Mutika 1203 & 122 & 144 & 90 & 114 \\
\hline 6 & $\begin{array}{l}\text { Mutika 4022 (Altai } \\
\text { Research Center of } \\
\text { Agrobiotechnologies) }\end{array}$ & 110 & 134 & 98 & 130 \\
\hline 7 & Inermis 1194 & 130 & 151 & 108 & \\
\hline & HCP05 & 9 & 7 & 5 & \\
\hline
\end{tabular}

The highest level of green mass harvesting of oat varieties was achieved in the conditions of 2018 and 2019. (table 2). It is explained by the high level of moisture availability in the period before ear formation of the oats, when both the vegetative mass and the leaf surface are being increased [11]. The yield of varieties ranged from 46.2 to $69.9 \mathrm{t} /$ ha in 2018 and from 47.2 to $57.4 \mathrm{t} /$ ha in 2019 . In the dry conditions of 2020 , the mean yield of varieties was $61-66 \%$ in comparison with the well-moisture years. We should note that in 2018 and 2019, in the first mowing, oat varieties pull through from crown rust, and during the second mowing, pustules were already found on the leaves.

The Mutika 1203 sample had the maximum yield of green mass in favorable years, which provided it with leadership in the results of a three-year study. Mutika 1201 was more stable and resistant to drought in 2020. In terms of average indicators for three years, the yield level of this variety is in second place. Also noteworthy is the Inermis 1194 naked sample, which forms a high yield of green mass under favorable conditions.

Table 2. Productivity of KSI oat varieties per green mass (2018-2020).

\begin{tabular}{|c|c|c|c|c|c|}
\hline \multirow{2}{*}{$\begin{array}{l}\text { Seq } \\
\text { No. }\end{array}$} & \multirow{2}{*}{ Variety } & \multicolumn{3}{|c|}{ On average, for two mowing, $\mathrm{t} / \mathrm{ha}$} & \multirow[b]{2}{*}{$\bar{X}$} \\
\hline & & 2018 & 2019 & 2020 & \\
\hline 1 & Irtysh 22, st. & 50.8 & 47.7 & 32.3 & 43.6 \\
\hline 2 & $\begin{array}{l}\text { Ural (Ural Research } \\
\text { Institute of Agriculture) }\end{array}$ & 46.2 & 47.2 & 32.9 & 42.1 \\
\hline 3 & Irtysh 33 & 61.8 & 53.1 & 35.2 & 50.0 \\
\hline 4 & Mutika 1201 & 56.9 & 56.8 & 38.0 & 50.6 \\
\hline 5 & Mutika 1203 & 69.9 & 57.4 & 34.6 & 54.0 \\
\hline 6 & $\begin{array}{l}\text { Mutika } 4022 \text { (Altai Re- } \\
\text { search Center of Agro- } \\
\text { biotechnologies) }\end{array}$ & 54.0 & 50.1 & 36.3 & 46.8 \\
\hline 7 & Inermis 1194 & 65.3 & 52.8 & 33.0 & 50.4 \\
\hline & $\mathrm{HCP}_{05}$ & 1.3 & 1.4 & 0.8 & \\
\hline
\end{tabular}

Morphologically, the oat is similar to other cereals. It may have a significantly different number of stems depending on the variety and cultivation conditions. The stem is plain and 
unbranched. The height of the stem to the apical spikelet in the panicle can be from 60 to $200 \mathrm{~cm}$. It is represented by a hollow straw of circular cross-section, divided into internodes by dense solid nodes (3...4). The oat stalk is smooth in most cases. Until maturation, the oat stalk has a green color and a waxy coating makes it bluish.

The stalk nodes have a slightly larger diameter than the internodes. The signs of pubescence and coloration of the nodes are of systematic significance.

The length of the internodes differs both in individual varieties and within a single plant. The length of the lower internodes is the smallest $(1-3 \mathrm{~cm})$, the ones following it to the top lengthen and reach $30-60 \mathrm{~cm}$.

The oat leaf is linear, drooping when ripe, consists of a leaf sheath; the base attached to the stalk node and covering the straw; a leaf blade and a ligula (ligula) at the junction of the leaf sheath into the leaf blade. According to the researchers, the ligule defines the length of the leaf sheath and leads to its increase from the lower leaf to the upper one.

The leaf sheaths in the upper and middle parts of the stalk are usually naked; pubescence of various degrees of severity is often shown on the lower ones. By color, it corresponds to the stalk; it may have a waxy coating. An oat leaf blade is also naked. Sometimes it is pubescent, and may have a waxy coating. Occasionally, up to two-thirds of the length of the leaf blade at the edges may have cilia. In the germination phase, the first oat leaf is twisted around the future stalk clockwise, which is a distinctive feature of the culture. The vertical arrangement of the leaves during the ear formation period is typical for forms resistant to lodging [12].

The maximum increase in the leaf surface of oats is seen in the stem elongation [10]. The weather conditions of the growing season of 2019 were most favorable for its formation in varieties (Table 3 ). The changeability of the leaf area was characterized as average $(\mathrm{CV}=23,0-45,8 \%)$. It was the largest in 2020 and the smallest in 2018.

Being an indicator that characterizes the photosynthetic activity of plants and is positively related to their productivity, the accumulation of dry biomass in ontogenesis is most extensively used. It captures the final balance of the processes of photosynthesis, respiration, the intake of ash elements and the intensity of growth. The data given by V. I. Bogachkov [13]] shows that oats accumulate $27.5 \%$ of dry matter by the stem elongation, $46 \%$ by the ear formation, and $85 \%$ by the milky stage $-85 \%$.

Our studies have shown that the conditions of the growing season of 2019 had a positive impact on the formation of dry biomass of oat plants. The weight of one plant is higher than in 2018 and 2020, by 0.55 and $0.95 \mathrm{~g}$, respectively, with an average variability of the characteristic $\mathrm{CV}=16.0 \%$ (table 3 ).

Table 3. Total assimilation area and dry biomass of oat plants, on average in the KSI nursery.

\begin{tabular}{|l|c|c|c|c|c|c|c|c|}
\hline \multirow{2}{*}{ Phenological phase } & \multicolumn{4}{|c|}{ Leaf area, $\mathrm{cm}^{2} /$ plant. } & \multicolumn{4}{c|}{ Air-dry substance, g plant. } \\
\cline { 2 - 10 } & 2018 & 2019 & 2020 & $\overline{\mathrm{X}}$ & 2018 & 2019. & 2020 & $\overline{\mathrm{X}}$ \\
\hline Ear formation & 151.5 & 156.3 & 106.8 & 137.9 & 4.40 & 4.95 & 4.00 & 4.45 \\
\hline $\max$ & 201.7 & 199.5 & 135.1 & - & 5.18 & 5.76 & 5.16 & - \\
\hline $\min$ & 100.6 & 126.0 & 81.8 & - & 1.86 & 4.17 & 3.84 & - \\
\hline $\mathrm{CV}, \%$ & 32.8 & 23.0 & 45.8 & - & 45.5 & 16.0 & 16.0 & - \\
\hline $\mathrm{HCP}_{05}$ & 18.6 & 18.6 & 24.9 & & 1.08 & 1.35 & 1.46 & \\
\hline
\end{tabular}

The oat harvest of the first sowing period in the green forage chain falls on the timespan between the mowing of clover and alfalfa [14]. Meanwhile, it is essential to get a highprotein, full-fledged feed for livestock.

The protein harvest from 1 ha of green oat mass, depending on the conditions of the year, variety and mowing period, was $0.454 \ldots 0.799$ t/ha (Table 4 ). The greatest yield of 
Crude protein is found in varieties a week after ear formation, i.e., in the first mowing. During the years with contrasting weather conditions, there is a significant difference in the protein content of all varieties. In 2019 it was $11.03 \ldots 11.48 \%$, in $2020-16.44 \ldots 14.88 \%$, depending on the mowing period.

Table 4. Protein harvesting from oat varieties for green food in 2019 and 2020.

\begin{tabular}{|c|c|c|c|c|c|c|c|c|c|}
\hline \multirow[b]{3}{*}{$\begin{array}{l}\text { Seq } \\
\text { No. }\end{array}$} & \multirow[b]{3}{*}{ Variety } & \multicolumn{4}{|c|}{2019} & \multicolumn{4}{|c|}{2020} \\
\hline & & \multicolumn{2}{|c|}{ the first mowing } & \multicolumn{2}{|c|}{ the second mowing } & \multicolumn{2}{|c|}{ the first mowing } & \multicolumn{2}{|c|}{ the second mowing } \\
\hline & & $\begin{array}{c}\text { Protein } \\
\text { content, } \\
\%\end{array}$ & $\begin{array}{c}\text { Crude } \\
\text { protein } \\
\text { harvest- } \\
\text { ing, } \mathrm{t} / \\
\text { ha }\end{array}$ & $\begin{array}{c}\text { Protein } \\
\text { content } \\
\text { a, \% }\end{array}$ & $\begin{array}{c}\text { Crude } \\
\text { protein } \\
\text { harvest- } \\
\text { ing, t } / \\
\text { ha }\end{array}$ & $\begin{array}{c}\text { Protein } \\
\text { content, } \\
\%\end{array}$ & $\begin{array}{c}\text { Crude } \\
\text { protein } \\
\text { harvest- } \\
\text { ing, t/ } \\
\text { ha }\end{array}$ & $\begin{array}{c}\text { Protein } \\
\text { content } \\
, \%\end{array}$ & $\begin{array}{c}\text { Crude } \\
\text { protein } \\
\text { harvest- } \\
\text { ing, } \mathrm{t} / \\
\text { ha }\end{array}$ \\
\hline 1 & Irtysh 22, st. & 9.85 & 0.481 & 11.52 & 0.537 & 16.70 & 0.468 & 15.23 & 0,492 \\
\hline 2 & Ural & 11.60 & 0.615 & 11.12 & 0.460 & 18.42 & 0.554 & 15.00 & 0,537 \\
\hline 3 & Irtysh 33 & 11.05 & 0.641 & 9.42 & 0.454 & 16.33 & 0.524 & 13.65 & 0,480 \\
\hline 4 & Mutika 1201 & 10.85 & 0.674 & 12.51 & 0.644 & 14.40 & 0.495 & 14.51 & 0,488 \\
\hline 5 & Mutika 1203 & 10.46 & 0.663 & 10.33 & 0.530 & 16.30 & 0.575 & 13.92 & 0,482 \\
\hline 6 & Mutika 4022 & 10.49 & 0.552 & 10.88 & 0.518 & 15.28 & 0.532 & 14.69 & 0,533 \\
\hline 7 & Inermis 1194 & 12.94 & 0.727 & 14.57 & 0.799 & 17.67 & 0.567 & 17.14 & 0,566 \\
\hline & Average & 11,03 & 0.622 & 11.48 & 0.563 & 16.44 & 0.531 & 14.88 & 0.511 \\
\hline
\end{tabular}

Regardless of the significant role of weather conditions in the accumulation of protein in the vegetative mass, the varietal differences in its content are significant. So, in the wet year 2019, the protein content in the vegetative mass of oat varieties averaged $11.26 \%$ according to experience, with fluctuations from $9.85 \%$ (Irtysh 22) to $12.94 \%$ (Inermis 1194) in the first moving and from $9.42 \%$ (Irtysh 33 ) to $14.57 \%$ (Inermis 1194) in the second mowing. In the dry 2020 , the protein content in the vegetative mass averaged $15.66 \%$ with an fluctuation amplitude from $14.4 \%$ (Mutika 1201) to $18.42 \%$ (Ural) in the first mowing and from $13.65 \%$ (Irtysh 33) to $17.14 \%$ (Inermis 1194) in the second mowing. The maximum harvest of crude protein in the years of research was in the naked variety Inermis 1194.

The correlation dependence of the yield of the green mass of oat varieties with the leaf area is also found. In all the years of research, an average relationship between these indicators was observed. It was the least in $2018(\mathrm{r}=0.42 \pm 0.21)$, average in $2019(\mathrm{r}=0.53 \pm 0.19)$. Even in 2020, at elevated air temperatures, together with a sufficient supply of moisture in the soil and with precipitation that fell during the necessary phases of crop development, the correlation coefficient was also average, but higher than in 2018 and 2019 $(\mathrm{r}=0.60 \pm 0.19)$.

Taking into account the data obtained, there is no connection between the yield of green mass and the protein yield, as well as between the leaf area and protein.

The topicality of developing oat varieties for the production of diverse feeds is noted in the paper by G. A. Batalova [15]. The new genotypes should combine grain and mowing productivity to the maximum degree with high product quality, resistance to lodging and immunity to diseases. Years of research at the Omsk Agrarian Research Center have shown that in most cases, varieties with high feed productivity had a grain yield at or below the standard of the zoned Orion variety.

The selection of parental pairs is the most complicated task of combinational selection. N. I. Vavilov [16] considered that the basis of selection work should be local adaptive populations. Meanwhile, it is essential to involve the world's diversity. Today, after field studies of varieties and evaluations by physiologists, technologists and immunologists, mainly American and Western European varieties are used in crosses. Based on the results of the evaluation, sources were determined for the creation of varieties adaptive to the complex of biotic and abiotic stress factors of the Siberian region, ensuring the formation of a high stable grain yield and feed mass. In order to create a new source material, the best varieties of 
laboratory selection, as well as foreign varieties from the collection nursery, are used as parent forms in hybridization. They are the following: D-25-EU, Kelsey, IL 85-1538 (CШA), Paul (Canada). The sources of Russian origin are also highlighted: Mirny, Kirovets, Compleksny, Universal 1, Cherkassky, Galop and the naked line LG-25 (Kemerovo selection).

Since 2018 and to the present time, the Omsk Agrarian Research Center has been studying a number of selection forms of moving oats of the new selection direction (Mutika 1201, Mutika 1203 and the naked variety Inermis 1194). These studies are performed in the nursery of the competitive variety trial. Totally, from 2018 to 2020, a new source material for green mass selection in the amount of 75 hybrid populations was developed by the hybridization method. The selection of elite heads from them is conducted for two or three years in different generations.

The selection of moving lines begins in the early selection nursery SP-2 with the use of the following techniques:

1. The sampling according to the original parent forms for green feed, the plots of which are locked together with the Irtysh 22 standard.

2. Visual evaluation of all samples in the nursery by the thickness of the stalk, the length and width of the leaf, the height of the plants.

3 . We select 10 plants in a row from each sample for estimation according to the techniques of the laboratory of genetics, physiology and biochemistry of plants. We cut them off with a pruner at a height of $10 \mathrm{~cm}$ from the ground, indicating the number on the paper label. After that, the selected plant samples are weighed on an electronic scale, followed by the selection of variety samples with a plant weight below the Irtysh 22 standard. The best numbers are used to define the leaf surface area $\left(\mathrm{cm}^{2} / \mathrm{pl}\right.$.) and the dry weight of the plant (g/ pl.) Then we test the varieties selected according to the results of the laboratory assessment in the control nursery.

On the basis of the obtained experimental data, we have identified the main characteristics of the model of varieties of paleaceous and naked oats of medium-ripened and mediumlate type for the natural and climatic zones of Western Siberia to the green food. The varieties are of great significance in stabilizing the production of high-quality feed. Meanwhile, it is essential to obtain genotypes which are maximally possible to combine a high yield of grain, green mass and dry matter with good product quality, resistance to lodging and disease damage.

\section{Conclusion:}

1. The 2019 weather conditions were more favorable for the formation of an assimilating area of plant leaves;

2. The promising varieties and lines of the feed direction are identified: Irtysh 33; the second year: Mutika 1201, Mutika 1203 and the naked variety Inermis 1194;

3. We have identified varieties with a high protein yield from 1 ha. First of all, this is the naked variety Inermis 1194, which is the leader in this indicator. Irtysh 33, Mutika 1201 and Mutika 1203 are also highly productive.

4. The protein harvest from the green mass of the Irtysh 22 in a wet year, unlike other paleaceous varieties, grows at the second cut;

5. Among the whole set of varieties, the naked variety Inermis 1194 is the most sensitive to an increase in moisture supply. Meanwhile, in a wet year, it provides a higher protein harvest at the second mowing than at the first one. As for the dry year, the yield of this indicator at the first and second mowing is kept at the same level. 
6. In order to create a new source material by hybridization, the best varieties of domestic selection, as well as foreign varieties from the collection nursery, are used as parent forms: D-25-EU, Kelsey, IL 85-1538 (USA), Paul (Canada).

\section{References}

1. M. Christiansen, Br pl f $1 \mathrm{f}$ en, 1-11 (1982)

2. A.A. Zhuchenko, Ag biol, 3-29 (2000)

3. N.A. Surin, Adaptive potential of Siberian grain varieties and ways to improve it (wheat, barley, oats), 596-611 (Novosibirsk, 2011)

4. Yu. A. Gulyanov, Agr, 6, 30-31 (2006)

5. V.V. Anikeev, Ph of pl, 8(3) (1961)

6. Methodological guidelines for determining the physiological parameters of wheat plants during variety study, (Moscow, 1982)

7. A.I. Ermakov, Methods of biochemical research of plants, 430 (Leningrad, Agropromizdat, 1987)

8. B.A. Dospekhov, Methodology of field study, 352 (Moscow, Agropromizdat, 1985)

9. D.V. Polyakov, Bull of the Tom St Un, 360, 188-192 (2012)

10. Weather monitoring in Omsk. URL: http://www.pogodaiklimat.ru/monitor.php?id $=28698$ (Accessed date: 07.07.2021)

11. G.Ya. Kozlova, Sib Bul of Agr Sc 10, 19-24 (2008)

12. Morphological properties of plants. URL: http://agro-portal.su/oves/2596morfologicheskie-osobennosti-rasteniy.html (Accessed date: 07.07.2021)

13. V.I. Bogachkov, Oats in Siberia and the Far East, 127 (Moscow, Rosselkhoizdat, 1986)

14. R.I. Polyudina, Clover in Siberia: a monograph, 348 (Novosibirsk, SFNCA RAN, 2017)

15. G.A. Batalova, Plant genetic resources as a strategic part of food, environmental and bioresource security, 5-11 (Saint Petersburg, 2009)

16. N.I. Vavilov, The scientific basis of wheat selection, 245 (Moscow-Leningrad, 1935) 